\title{
Grupo Químicos Jovens
}

\section{Portuguese Young Chemists AWARD 2012}

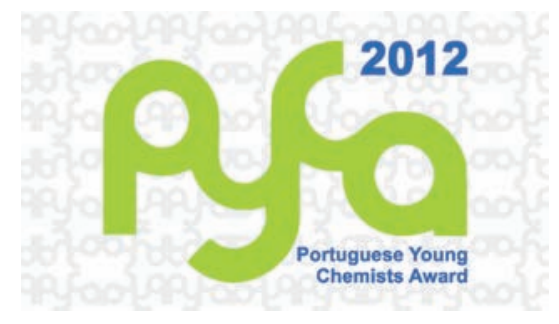

O Grupo de Químicos Jovens (GQJ) vai atribuir o Portuguese Young Chemists Award 2012 (PYCA 2012). Este prémio, agora na sua segunda edição, pretende distinguir um jovem químico pelo trabalho de investigação realizado no âmbito do seu doutoramento. Para submeter uma candidatura a este prémio, o jovem químico (com menos de 35 anos a 31 de Dezembro de 2011 e tendo obtido o grau de Doutor durante os anos civis de 2010 e 2011) deverá redigir um artigo de divulgação científica sobre a temática da sua tese, enfatizando a relevância do seu trabalho para a Sociedade em geral. O prazo de candidaturas está aberto desde 1 de Dezembro de

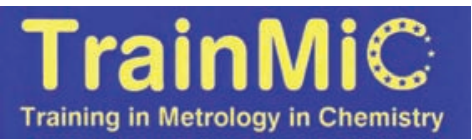

O programa TrainMiC $^{\circledR}$ de aprendizagem ao longo da vida, http://www. trainmic.org, desenvolvido pelo European Commission's Joint Research Centre (JRC), comemora o seu $10^{\circ}$ aniversário. Com mais de 6500 pessoas na Europa a terem recebido formação avançada em medições químicas, o programa continua em crescimento, com novas equipas de formação nacional anunciadas para a Bielorrússia, Irlanda, Lituânia e Bélgica.

É crescente o número de empregadores que exigem pessoal de laboratório qualificado para trabalhar de acordo com a principal norma internacional usada por laboratórios de ensaio e calibração, ISO/IEC 17025. Exemplo disso é o facto de a Federação Europeia
2011 até 15 de Fevereiro de 2012. O vencedor verá o seu artigo de divulgação científica publicado neste Boletim e terá ainda a possibilidade de apresentar uma comunicação oral no $3^{\text {rd }}$ Portuguese Young Chemists Meeting (3PYCheM), a decorrer de 9 a 11 de Maio de 2012 na Faculdade de Ciências da Universidade do Porto, onde também terá lugar a cerimónia de entrega do prémio. Todas as informações necessárias à submissão de candidaturas estão disponíveis em www.spq.pt/gqj/.

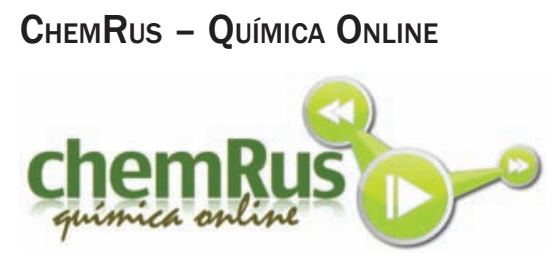

O GQJ lança este ano a primeira edição do concurso ChemRus - Química Online, direccionado para alunos de Química do Ensino Secundário. A participação neste concurso consiste na produção de um vídeo com a exe- cução de uma experiência de química, acompanhada de uma ficha científica. O melhor vídeo será distinguido após avaliação por um Júri a divulgar, tendo em conta a correcção científica e relevância da experiência executada, assim como a originalidade do vídeo produzido. O GQJ gostaria de convidar os professores de química do Ensino Secundário a participar activamente no ChemRus, incentivando os seus alunos a concorrer e orientando a componente laboratorial desta actividade. O prémio a atribuir aos alunos e à Escola Secundária do vídeo vencedor será divulgado brevemente.

O prazo para candidaturas decorre desde 1 de Dezembro de 2011 até 15 de Março de 2012. Toda a informação necessária para concorrer, incluindo o Regulamento do concurso, está disponível em www.spq.pt/gqjl.

\section{Vânia Calisto, Sérgio Santos e Mariana Sardo \\ (Vânia.calisto@ua.pt) Grupo de Químicos Jovens}

\section{$10^{\circ}$ Aniversário do Programa TrainMic ${ }^{\circledR}$ Assinalado em Franca Expansão}

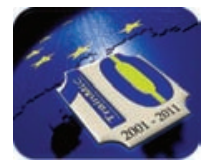

das Indústrias Químicas (CEFIC) e o Grupo de Alto Nível sobre a Competitividade da Indústria Química, da UE, terem identificado o ensino e a formação como uma iniciativa estratégica.

Reconhecendo um défice de competências em metrologia química (a ciência das medições), o JRC's Institute for Reference Materials and Measurements (JRC-IRMM), http://irmm. jrc.ec.europa.eu, pôs em prática uma colaboração entre especialistas para desenvolver um programa harmonizado e especializado de formação de pessoal de laboratório.

O programa que daí resultou é implementado em quase 20 países, por mais de 80 formadores reconhecidos pela Comissão Europeia - cada um dos quais assinou um acordo, JRC User License Agreement, de utilização do conteúdo do curso TrainMiC ${ }^{\circledR}$. Actualmente, o programa TrainMiC ${ }^{\circledR}$ está disponível em catorze línguas, e mais duas (russo e francês) serão brevemente adicionadas à lista.

Dotar as pessoas com as competências adequadas para as tarefas do presente e do futuro é um elemento chave das iniciativas emblemáticas da Comissão Europeia, nomeadamente "Agenda de novas competências e profissões" e "Juventude em Movimento".

Recentemente, o Director do JRC-IRMM, Krzysztof Maruszewski, comentou: "A Europa precisa de técni- 